\title{
TEACHERS' PERCEPTIONS OF THE ROLE OF PRAGMATICS IN THE EFL CLASSROOM
}

\section{Irina Ivanova*}

\begin{abstract}
The need to prepare foreign language learners for successful cross-cultural communication increases the importance of developing their pragmatic competence. However, due to different factors, classroom procedures are still largely dominated by form-focused instruction and manipulation, and the focus on pragmatic phenomena remains somewhat neglected or marginalised. The present study looks into teachers' awareness of the pragmatic domain and its impact on their attitudes and approaches to developing the pragmatic component of communicative competence. Data analysis showed that most of the teachers are aware of the main issues involved in teaching pragmatic competence. They were able to name different speech acts and give a variety of appropriate examples. However, about 43\% couldn't name any speech acts or gave wrong answers. Teachers' awareness of pragmatic appropriacy was demonstrated in the extensive lists of topics and behaviours which they considered inappropriate in cross-cultural encounters.
\end{abstract}

Key words: pragmatics, awareness, attitudes, foreign language teaching

\section{Introduction}

The trends of globalisation and the increasing role of intercultural communication are constantly posing new challenges to foreign language teaching. One of the aspects which is of primary importance in school education is the focus on language use in various social contexts and the students' ability to understand and produce language which is not only correct, but is also appropriate to those contexts. Whereas classroom instruction focuses mainly on students' understanding of semantic information, carried by language items themselves, pragmatic phenomena in general "involve information that is generated by, or at least made relevant by, acts of using language" (Bach, 2006, p.148). The need for an increased awareness of language in use is invariably linked to a change in the attitudes towards cultural differences, and the acceptance of existing diversity in communication styles and strategies employed by representatives of different cultures.

Although the focus on pragmatics is part of instructed language learning, it does not figure prominently in research literature, mainly due to the "relative neglect of pragmatics in second language acquisition in general" (Rose, 2005, p. 385). The main issues addressed are the teachability of pragmatics, the relative

* Assoc. Professor PhD at Shumen University, Department of English Studies, Shumen, Bulgaria, e-mail: irina.ivanova@shu.bg. 
benefits of instruction versus exposure, and whether different approaches to instruction yield different results (Rose, ibid). A similar neglect characterises the treatment of non-verbal communication, and the interpretation of non-verbal acts, such as, for example, the multiple possible meanings of a handshake, which, depending on the contexts might be considered greeting, introduction, sealing a deal, congratulations, or bidding farewell (Bach, 2006).

Recent research in the area of pragmatics tends to adopt a larger frame, extending beyond the limitation of cross-cultural studies of isolated speech acts and politeness phenomena viewed as static entities which ignore human agency (see LoCastro, 2012). As Larsen-Freeman (1997) points out, a more adequate holistic approach to second language acquisition sees language structures as inherently tied to the social contexts they are used in. Moreover, a modern view on pragmatics emphasises achievement and success, and avoids focusing on instances of pragmatic failure. However, appropriate pragmatic perception and production is difficult to achieve without the active intervention of the teacher, who is seen as a major source of carefully measured explicit instruction. As research evidence shows, simple exposure to target language pragmatics is insufficient as students in general fail to notice context-based pragmatic features (see Schmidt, 1993; Bardovi-Harlig, 2001).

The evidence for the teachability of pragmatic features, as well as the positive results from using instruction rather than simply relying on exposure, raise the importance of the teacher as a source of information and facilitator, especially in educational contexts where English is a foreign language and is not widely spoken in a country. As Erton (2017, p.176) points out, "teachers play a significant role in developing the students' pragmatic awareness and, in most cases, they become the only role model". Hence the need to research teachers' awareness of pragmatics, its nature and scope, and the way they can provide pragmatic instruction to their students.

\section{Previous research in the field}

One of the most comprehensive recent studies of teachers' knowledge, beliefs and practices in teaching interlanguage pragmatics was conducted by Ishihara (see Ishihara, Cohen, 2010). She identified the following key aspects of knowledge: pragmatic variation and pragmatic norms in the target language, and metapragmatic knowledge how to teach and assess pragmatics and pragmatic ability. Teachers also need to be aware of learners' identities, cultures, proficiency, and be familiar with the pragmatic-focused curriculum and the role of L2 pragmatics in educational contexts.

In research literature pragmatic competence is closely linked to pragmatics, defined by Leech (1983) as the study of how utterances have meanings in 
situations. Crystal (1997) puts forward another feature of pragmatics, namely the fact that it studies language "from the point of view of users, the choices they make, the constraints they encounter in using language in social interaction, and the effects their use of language has on other participants in the act of communication" (Crystal, 1997, p. 301). According to Richards and Schmidt (2002), pragmatics is the study of the use of language in communication, particularly the relationships between sentences and the contexts and situations in which they are used. It studies the way in which the interpretation and use of utterances depends on our knowledge of the real world; the way speakers use and understand speech acts; and the way the structure of sentences is influenced by the relationship between the speaker and the hearer.

The term pragmatic competence was first used by Chomsky (1980, p. 224) to indicate the "knowledge of conditions and manner of appropriate use in conformity with various purposes". He distinguished it from grammatical competence which was limited to the knowledge of the language form and meaning. Canale and Swain (1980) included pragmatic competence in their model of communicative competence, and defined it as the knowledge of contextually appropriate language use. In a later work Canale (1988) described pragmatic competence as including illocutionary competence (the knowledge of the pragmatic conventions), and sociolinguistic competence (knowledge of the sociolinguistic conventions) for performing language functions appropriately in a given context. Pragmatic competence was a key component in Bachman's model of language competence (1990), where it stood for the ability to use the language to express a wide range of functions, whose illocutionary force depended on the sociocultural context in which they were uttered. Pragmatic competence was further described as consisting of the speaker's ability to use language for different purposes; the listener's ability to get past the language and understand the speaker's real intentions; and the command of the rules by which utterances come together to create discourse (Bialystok, 1993).

More recent researchers (see Rose, 1999; Kasper, Rose, 2001) agree with the earlier distinction (see Thomas, 1983; Leech, 1983) between pragmalinguistics (the ability to use available linguistic resources) and sociopragmatics (the social perceptions underlying participants' interpretation and performance of communicative action).

The study of pragmatics is invariably linked to speech acts and the levels of their realisation, called locutionary, illocutionary and perlocutionary, and described by Austin (1975) as what one is saying, what one does in saying it, and what one does by saying it. Successful communication is based not only on recognising the meaning of a message and interpreting the speaker's intentions, but also in performing, or complying with it through relevant behaviour. Based on Austin's (1975) and Searle's (1976) classifications of speech acts, Bach and Harnish (1979) differentiate between four types: 
1. Constatives, such as affirming, alleging, announcing, answering, attributing, claiming, classifying, concurring, confirming, conjecturing, denying, disagreeing, disclosing, disputing, identifying, informing, etc.

2. Directives, such as advising, admonishing, asking, begging, dismissing, excusing, forbidding,

instructing, ordering, permitting, requesting, requiring, suggesting, urging, warning, etc.

3. Commissives, such as agreeing, betting, guaranteeing, inviting, offering, promising, refusing, volunteering, etc.

4. Acknowledgments, such as apologizing, condoling, congratulating, greeting, thanking, accepting, etc.

Another area of study of pragmatics is the interrelation between speaker's intentions in using a speech act and its effect on the listener's self-image. This effect is addressed by the politeness theory, first proposed by Brown (1987), and linked to idea of face-threat and imposition, and the need to mitigate them by using different politeness strategies. More recently, there have been attempts to extend politeness theory to cover impoliteness (see Culpeper, Bousfield, Wichmann, 2003), who propose a set of impoliteness strategies that mirror Brown's politeness strategies. For example, they propose bald on record impoliteness used when the speaker makes it obvious that he or she is threatening someone's face. Similarly, positive impoliteness threatens the listener's positive face by making him or her feel excluded or unvalued, whereas negative impoliteness threatens listener's negative face by creating negative associations, interrupting or restricting his or her freedom to speak. In addition to these forms of direct impoliteness, here is also indirect impoliteness, which can be achieved through insincere politeness, sarcasm, or not performing the expected polite speech act.

\section{Research questions and data collection}

The article presents and discusses the results of a survey conducted with 30 teachers of English who work in secondary schools in the town of Ruse and Ruse region in North-East Bulgaria. The aim of the survey was to research teachers' awareness of pragmatics and its role in foreign language teaching and learning. Given the fact that pragmatics is somewhat neglected in course books, or at least not explicitly taught or brought to the foreground, I expected to find some problems and gaps in teachers' knowledge and awareness of pragmatic issues. The survey was conducted immediately before a training seminar, organised by the local inspectorate as part of teachers' continuous professional development plan. The teachers had about 30 minutes to answer the questions in the survey, 
so they didn't have time to research their answers, and had to rely entirely on their prior knowledge and experience.

The survey included both open-ended questions and statements to which teachers had to agree or disagree (see Appendix 1). They had to define pragmatic competence and name some speech acts which language learners need to acquire as part of foreign language curriculum. The teachers were also asked to reflect on their teaching approaches and preferences in addressing politeness issues in class. The statements to which they were asked to agree or disagree are related to their familiarity with pragmatics, their beliefs about its importance, their own pragmatic competence, and the treatment of different politeness phenomena, such as pragmatic norms, errors, appropriateness, as well as the effect of polite or impolite verbal behaviour. The teachers had to give examples of three common speech acts: polite request, refusal and apology, and examples of inappropriate in the target culture conversation topics, verbal and nonverbal behaviour. The speech acts in the survey were chosen as they represent three of the most common communicative acts: directives (requests), commissives (refusals) and acknowledgements (apologies). The first two are considered inherently threatening to the negative face of the listener, as the speaker, especially in making requests, limits the listener's freedom to act by trying to commit the addressee to an action, or prohibiting action on their part. Brown (1987) suggested three strategies for mitigating the face threat in such cases: negative politeness, which reduces the magnitude of the imposition and shows respect for the listener's negative face; positive politeness, which emphasises the listener's positive face, and indirectness, which gives the speaker an option to refuse or object. One of the reasons for including this question in the survey was to see if the teachers are aware of these strategies in choosing their examples.

Lack of politeness can also be manifested in choosing culturally sensitive or inappropriate conversation topics, or by behaving in a way which representatives of other cultures might find rude or offensive. Questions 5 and 6 were aimed at identifying teachers' awareness of such topics and behaviours.

To sum up, raising awareness of pragmatics is the first step in helping teachers make use of the links between interlanguage pragmatics and second language acquisition.

\section{Data analysis and discussion}

\subsection{Defining pragmatic competence}

In the first question the teachers had to define pragmatic competence. 7 out of 30 teachers (about 23\%) did not provide a definition, which suggests that they either did not know what it is, or were not sure how to define it. In general, the 
responses show that most teachers are familiar with some of the key aspects of the concept. However, some of the definitions they gave were too general, incomplete or vague (the ones marked with * below). Here are examples of how the teachers defined pragmatic competence:

- ability to use language effectively according to the situation or topic

- ability to use knowledge in real-life situations

- expressing oneself in an appropriate way*

- communicative competence involving "paralinguistic instruments" verbal and non-verbal interaction*

- ability to use the language*

- ability to use language appropriately*

- ability to use appropriate language in real-life situations in a certain cultural background

- it is linked to situational use

- it means asking the right questions in the situation*

- the ability to use language for meaningful communication*

- the ability to act adequately in real-life situations using the foreign language

- it is linked to learning rules and studying examples*

- using the language fluently in real-life situations

- practice-based learning*

- using one's knowledge and skills correctly and appropriately.

\subsection{Awareness of speech acts}

In response to question 2 the teachers named a variety of speech acts. The average number of speech acts each teacher named was 3 to 4 . The speech acts (or, as they are called in most course books, language functions) which the teachers mentioned were as follows (the number next to the speech act indicates how many teachers gave this answer):

- greeting someone - 4

- making excuses - 3

- making proposals - 2

- apologies - 2

- complaints - 2

- giving opinions

- saying goodbye 
- asking for help

- asking for information

- asking questions - 2

- offers

- expressing agreeing/ disagreeing

- comparing

- giving introductions

- making suggestions

- giving and following instructions

- guessing,

- expressing wishes.

About $13 \%$ of all teachers could not name any speech acts, and about 30\% gave wrong or irrelevant answers, which shows that a lot of teachers do not understand what a speech act is. Some of these answers were:

- to be able to understand when they listen and read*

- to represent ideas in a creative way*

- to prove they know the language when they speak*

- to speak on different topics, such as internet, technologies, fashion*

- dialogues, simulations, problem-solving tasks*

- to be able to communicate and deal with information*.

In two responses speech acts were confused with situations in which communication takes place: in a shop, on the phone, in an interview. The figures confirmed my expectations that some of the teachers might lack knowledge of pragmatics, and speech acts in particular. However, the number of teachers who had problems with pragmatics was larger than expected.

\subsection{Beliefs and practices in teaching pragmatics}

In the third part of the survey, the teachers had to agree or disagree with some statements related to their beliefs and practices in teaching pragmatics, and some of its key aspects, such as politeness, pragmatic appropriateness, pragmatic norms, impolite and aggressive behaviour. The table below shows the teachers' responses in \%. The numbers from 1 to 5 stand for: 1 . strongly disagree, 2 . disagree, 3 . neither agree nor disagree, 4. agree, and 5. strongly agree, respectively. 
Table 1. Teachers' beliefs about pragmatics in \%

\begin{tabular}{|c|c|c|c|c|c|}
\hline & 1 & 2 & 3 & 4 & 5 \\
\hline 1. I am familiar with the concept of pragmatics. & 7 & 7 & 14 & 65 & 7 \\
\hline $\begin{array}{l}\text { 2. Pragmatic competence is important for language } \\
\text { learners. }\end{array}$ & 0 & 0 & 14 & 28 & 58 \\
\hline $\begin{array}{l}\text { 3. I evaluate my own pragmatic competence as very } \\
\text { good. }\end{array}$ & 4 & 0 & 26 & 56 & 14 \\
\hline $\begin{array}{l}\text { 4. The instruction of pragmatic competence should } \\
\text { be part of an effective language teaching program. }\end{array}$ & 0 & 0 & 14 & 48 & 38 \\
\hline $\begin{array}{l}\text { 5. Learners' pragmatic competence should be part of } \\
\text { an effective language testing program. }\end{array}$ & 0 & 4 & 23 & 50 & 23 \\
\hline $\begin{array}{l}\text { 6. I make my students aware of the significance of } \\
\text { pragmatic competence in language learning. }\end{array}$ & 4 & 0 & 23 & 50 & 23 \\
\hline $\begin{array}{l}\text { 7. I draw my student's attention to pragmatic } \\
\text { appropriateness. }\end{array}$ & 4 & 4 & 26 & 50 & 16 \\
\hline 8. I correct learners' pragmatic errors systematically. & 0 & 8 & 38 & 50 & 4 \\
\hline 9. Politeness is an important aspect of pragmatics. & 0 & 0 & 23 & 40 & 37 \\
\hline 10. Politeness is culture-specific. & 0 & 0 & 23 & 33 & 44 \\
\hline $\begin{array}{l}\text { 11. It is important for students to be aware of } \\
\text { politeness norms when speaking English. }\end{array}$ & 0 & 4 & 8 & 22 & 66 \\
\hline $\begin{array}{l}\text { 12. Students sensitive to impolite or aggressive verbal } \\
\text { behaviour. }\end{array}$ & 0 & 4 & 22 & 37 & 37 \\
\hline
\end{tabular}

The figures show that more than $70 \%$ of the teachers think that they know what pragmatics is. The remaining $30 \%$ fall into two groups: those who are not familiar with it, and those who are not sure how much they know about it. Irrespective of some teachers' lack of knowledge in the field, about $86 \%$ agree that pragmatic competence is important for language learners. $70 \%$ of teachers evaluate their own pragmatic competence as very good, which corresponds to the figures for their familiarity with pragmatics. Most respondents think that pragmatic competence should be taught and tested as part of an effective language teaching programme. This is further supported by teachers' personal commitment to raising students' awareness of pragmatics and pragmatic appropriateness. However, about half of the teachers $(46 \%)$ admitted to not treating students' pragmatic errors systematically. $77 \%$ of all teachers agree or strongly agree that politeness is an important aspect of pragmatics and that it is culture specific. The highest percent of teachers (66\%) strongly agree that it is important for students to be aware of politeness norms when speaking English. However, fewer of them believe that students are sensitive to impolite or aggressive verbal behaviour. The last finding supports the idea that it is necessary to explicitly draw students' attention to ways of avoiding impoliteness and aggression in communication, especially in cross-cultural encounters. 


\subsection{Sampling key speech acts: requests, refusals and apologies}

In the next part of the questionnaire the teachers had to give examples of three speech acts, which are frequently taught and featured in course books: polite requests, polite refusals and polite apologies. As research shows, some speech acts, such as requests, receive more attention than others (Barron, 2003; Achiba, 2003; Schauer, 2006), and in general, lower proficiency learners use more direct requests than the higher proficiency learners (Hill, 1997). There are 5 stages in the development of requests, including pre-basic, formulaic, unpacking, pragmatic expansion and fine-tuning (see Kasper, Rose, 2002). The examples teachers gave reflect these stages and can be divided into two types: 1. phrases for asking other people to do things, and 2. asking to do things oneself. Here are some of the examples teachers gave for polite requests (if more than one teacher gave the answer, the number is given in brackets):

\section{Type 1:}

- Could you + verb (4)

- Can you + verb (3)

- Could you possibly + verb

- Would you mind + verb + ing (3)

- Would you + verb (4)

- Would you ... please

- Would you like to + verb

- Will you be so kind to + verb* (4). All the examples of this phrase were incorrect, with missing as: cf. Will you be so kind as to + verb.

- Will you ....please

- Do you mind + verb + ing

- Excuse me + could you, can you, will you...

\section{Type 2:}

- Can I+verb (4)

- Could I+verb (4)

- $\quad$ Would you mind if I + verb (2)

- May I+verb ..., please (2)

- $\quad M a y I+$ verb

- $\quad$ Excuse me + may I, can I...

In general the teachers gave a variety of appropriate examples, which shows that they are familiar with this speech act and the different ways in which it can be expressed with a varying degree of politeness. However, there were some 
inappropriate examples, which sound more like offers to do something, rather than polite requests:

- Could I offer you a drive?*

- Shall I help you?*

- Shall I open the window?*

- May I help you?*

As a commissive face-threatening act, refusals could threaten the negative face of the listener, as they require refraining from future action. They can also threaten listener's positive face as they constitute rejection (see Barron, Warga, 2007). Being a second pair part in a conversation exchange, refusals depend on the initiating phrase, which can be a request, suggestion, invitation or offer. Bebee, Takahashi and Uliss-Weltz (1990) categorize refusals depending on the degree of directness they express into semantic formulas and adjuncts. Direct semantic formulas consist of performative refusals (I refuse...) or nonperformative statements (I can't...; I don't think so...). Indirect refusals might be phrased as apologies, regrets, wishes, excuses, reasons or explanations for not complying with the request, suggestion, etc. They can also suggest an alternative, or promise future acceptance. The adjuncts that might be added to both direct and indirect refusals can express positive opinion, empathy, gratitude, appreciation of the first pair part, or just be fillers, like $u h$, well, oh, etc. (see Bebee et al., 1990). Some of the examples for polite refusals the teachers gave involve:

- Sorry, I can't + verb

- I'm afraid I can't + verb

- I'm terribly/really/very sorry, but...

- I would love to, but...

- I'm afraid this is beyond me

- Sorry + explanation (Sorry, but I'm very busy today)

- Sorry + promise (Sorry, I'll do it another time)

- Sorry, I'd rather not

- Unfortunately I can't + verb

- I would be glad, but...+ explanation

- I wish I could but...+ explanation

There were a few inappropriate examples, which are either wrong in terms of language, or do not express the speech act of refusal, such as:

- I wish I would help you*

- I won't be able to help you*

- I don't think so* 
- I'm sorry I couldn't come*

In Bach and Harnish's typology (1979), the speech act of apology is defined as belonging to the class of acknowledgements, together with condolences, congratulations, greetings, thanking, accepting, etc. Previous studies on apology, such as Bergman and Kasper (1993), Blum-Kulka et al. (1989), Olshtain and Cohen (1983), Trosborg (1987), and Rose (2000) suggested that the use of apology strategies is closely linked to learners' proficiency level and is contextspecific. Research also suggests that the acquisition of L2 apology starts from the formulaic stage, in which learners acquire the routine formula expressing regret (I'm sorry/ sorry) first and then with increasing proficiency combine the formulaic Sorry with other apology adjuncts (Chang, 2009). However, some studies found that even when having access to a full range of apology strategies, beginners cannot master culture-dependent strategies. Peneva (2016) maintains that the teachers should first explain the semantic meanings of different apology patterns (e.g. Sorry, I apologise, I regret), making clear the feelings they refer to (e.g. guilt, regret, shame, etc.), and then clarify the form, or the syntactic patterns they can have. Learners also need to be made aware of the significance of social power, social distance and imposition when choosing the right form of apology. Further research is needed in order to understand whether the low use of some apology strategies such as request for forgiveness and lack of intent is due to L1 transfer (Chang, 2009).

The examples given by the teachers in the present survey confirm that in order to make the apology more polite, the speaker needs to add an explanation, promise or an intensifier, such as very, really, terribly. Here are some of the examples teachers gave:

- I'm sorry. How impolite of me.../how careless of me

- I'm sorry. It's my fault

- I'm sorry. I'll be more careful next time

- I'm really sorry for.../ about...

- I apologise for...

- Please accept my apologies

- I'd like to apologise for...

- I do apologise for...

- I'm sorry for bothering you...

- I beg your pardon

There were a few wrong answers, such as:

- I regret to tell you...*

- Sorry to bother you*

- I'm afraid I can't...* 


\subsection{Inappropriate discussion topics, verbal and non-verbal behaviour}

Pragmatic appropriacy concerns not only the use of speech acts but also speakers' awareness of conversation topics and small talk which can be sensitive or abusive for representatives of a different culture. Teaching materials often feature appropriate discussion topics and give students useful language in the form of ready-to-use phrases and conversational gambits which they can use in certain contexts. Some course books even draw students' attention to topics which they have to avoid or be careful with in cross-cultural communication. For example, the Cambridge University Press course book English Unlimited Elementary, in its Across cultures section raises learners' awareness of topics, which "are OK or not OK to talk about with people you don't know very well" (Tilbury, Clementson, Hendra, Rea, 2013, p. 31). The suggested topics involve age, religion, money, work, politics, health, home, and family.

In the present survey, 5 of the teachers did not answer the question. The other 25 listed the following topics as inappropriate when speaking with British or American people (the number of times a topic is mentioned is given in brackets):

- money/salary (8)

- Brexit (when speaking with British people) (7)

- religion (5)

- personal questions (4)

- politics (4)

- gender issues (3)

- migrants (3)

- ethnicity (skin colour, origin) (2)

- history (talking about Bulgarian history with foreigners who don't know much about it)

- the mafia

- slavery (with American people)

- Vietnam war and Middle-East conflicts (with Americans)

- racism/white supremacy (with both Americans and British)

- insulting the Queen or the monarchy (with British)

- president Trump (with Americans)

- British colonial past

- treatments of Native Americans in the USA

The teachers were less sure about inappropriate verbal and non-verbal behaviour in cross-culture communication. One third of them did not answer the question. The other suggestions involve: 
- It all depends on the situation and the participants in communication

- impolite or rude language

- calling someone who is Irish or Scottish English

- mockery

- loud laughter or speech

- sexist language

- verbal attacks on the Royal family

- using slang

- two-fingers gesture ( $V$-sign with the palm facing inward)

- middle finger

- excessive gesticulation

- nodding and shaking head the Bulgarian way to confuse foreigners

\section{Conclusion and implications}

The results of the survey showed that the majority of teachers are aware of the main issues involved in teaching the pragmatic component of communicative competence. Their definitions of pragmatic competence show familiarity with the key aspects of the concept, although some of the definitions were too general, incomplete or vague. This might be due to the fact that in their practice teachers do not need to demonstrate declarative knowledge of pragmatics by providing definitions; it is sufficient for them to be aware of what pragmatic knowledge involves and how it can be turned into input for students effectively.

More than half of all teachers were able to name at least four different speech acts, but it is worrying that about $43 \%$ of them couldn't name any speech acts or gave incorrect answers. This might be explained by the fact that the term speech act is mostly avoided in course books, whose authors give preference to terms like grammar and functions. Another explanation might be that a course in pragmatics is not an obligatory part of future teachers' pre-service preparation, in which the emphasis lies on studying morphology, syntax, and semantics. Although a lot of of teachers had problems listing a variety of speech acts, they managed to give appropriate and varied examples of requests, refusals and apologies.

As for the teachers' beliefs about pragmatics, it is important that irrespective of some gaps in their knowledge in the field, about $86 \%$ of the teachers agree that pragmatic competence is important for language learners and should be taught and tested as part of any effective language teaching curriculum. Most teachers thought that politeness is an important culture-specific aspect of pragmatics, and students need to be aware of the target language politeness norms. The teachers gave a variety of appropriate examples, demonstrating their familiarity 
with the respective speech acts and the different ways in which they can be expressed with a varying degree of politeness.

Teachers' awareness of pragmatic appropriacy was demonstrated in the extensive lists of topics and behaviours which they considered inappropriate in certain cross-cultural encounters. This awareness is a prerequisite for increasing learners' intercultural knowledge and preparing them for successful functioning in multi-lingual and multi-cultural environments. However, as Eslami-Rasekh (2005, p. 207) points out, "it is essential that learners be informed of the various options offered by the pragmatic system of English without being coerced into making particular choices regarding those options". The teachers themselves admit to finding it difficult to treat students' pragmatic errors systematically. This implies that further work is needed to equip them with knowledge and skills which will help them solve this problem and sensitise their students to the negative effects of impolite or aggressive verbal behaviour. This supports the idea that it is necessary to explicitly draw students' attention to ways of avoiding impoliteness and aggression in communication, especially in crosscultural encounters.

\section{References:}

Achiba, M. (2003). Learning to request in a second language: Child interlanguage pragmatics. Multilingual Matters, Clevedon, UK.

Austin, J. L. (1975). How to do things with words (Vol. 1955). Oxford: Oxford University Press.

Bach, K. (2006). Speech acts and pragmatics. In M. Devitt, \& R. Hanley (Eds.), The Blackwell guide to the philosophy of language. Malden, MA: Blackwell Publishing, 147167.

Bach, K., \& Harnish, R. (1979). Linguistic communication and speech acts. Cambridge, Mass.: MIT Press.

Bachman, L. (1990). Fundamental considerations in language testing. Oxford: Oxford University Press.

Bardovi-Harlig, K. (2001). Evaluating the empirical evidence of the need for instruction in pragmatics. In K. Rose \& G. Kasper (Eds.), Pragmatics in language teaching, (pp. 1332). Cambridge: Cambridge University Press.

Barron, A. (2003). Acquisition in interlanguage pragmatics: Learning how to do things with words in a study abroad context. Amsterdam: John Benjamins.

Barron, A., \& Warga, M. (2007). Acquisitional pragmatics: focus on foreign language learners. Intercultural Pragmatics 4(2), 113-127.

Beebe, L. M., Takahashi, T. \& Uliss-Weltz, R. (1990). Pragmatic transfer in ESL refusals. In R., C. Scarcella, E. S. Andersen, \& S. D. Krashen (Eds.), Developing Communicative 
Competence in a Second Language, (pp. 55-73). New York: Newbury House Publishers.

Bergman, M., \& Kasper, G. (1993). Perception and performance in native and non-native apology. In G. Kasper, \& S. Blum-Kulka (Eds.), Interlanguage Pragmatics, (pp. 82-107). New York: Oxford University Press.

Bialystok, E. (1993). Symbolic representation and attentional control in pragmatic competence. In G. Kasper, \& S. Blum-Kulka (Eds.), Interlanguage Pragmatics, (pp. 43 57). New York: Oxford University Press.

Blum-Kulka, S., House, J., \& Kapser, G. (1989). Cross-cultural pragmatics: Request and apologies. Norwood, NJ: Ablex.

Brown, P. (1987). Politeness: Some universals in language usage (Vol. 4). Cambridge: Cambridge University Press.

Canale, M. (1988). The measurement of communicative competence. Annual Review of Applied Linguistics, 8, 67-84.

Canale, M., \& Swain, M. (1980). Theoretical bases of communicative approaches to second language teaching and testing. Applied Linguistics, 1(1), 1-47.

Chang, Y.F. (2009). How to say no: an analysis of cross-cultural difference and pragmatic transfer. Language Sciences. 31 (4), 477-493.

Chomsky, N. (1980). Rules and representations. New York: Columbia University Press.

Crystal, D. (1997). A dictionary of linguistics and phonetics. 4th edition. Cambridge, MA: Blackwell.

Culpeper, J., Bousfield, D., \& Wichmann, A. (2003). Impoliteness revisited: With special reference to dynamic and prosodic aspects. Journal of Pragmatics, 35(10), 1545-1579.

Erton, E. (2017). Raising EFL students' awareness of pragmatic conventions in forming intercultural competence. In Todorova et al. (Eds.). Studies in Linguistics, Culture and FLT, Vol.2, 169-183.

Eslami-Rasekh, Z. (2005). Raising the pragmatic awareness of language learners. ELT Journal, Vol.59/3, 199-208.

Hill, T. (1997). The development of pragmatic competence in an EFL context. Unpublished doctoral dissertation, Philadelphia: Temple University.

Ishihara, N., \& Cohen, A. D. (2014). Teaching and learning pragmatics: Where culture and language meet. New York: Routledge.

Kasper, G., \& Rose, K. (2001). Pragmatics in language teaching. Cambridge: Cambridge University Press.

Kasper, G., \& Rose, K. (2002). Pragmatic development in a second language. Language Learning 52 (Suppl. 1).

Larsen-Freeman, D. (1997). Chaos/ complexity science and second language acquisition. Applied Linguistics, 18/2, 141-165.

Leech, G. N. (1983). Principles of pragmatics. London: Longman.

LoCastro, V. (2012). Pragmatics for language educators: A sociolinguistic perspective. New York: Routledge.

Olshtain, E., \& Cohen, A. (1983). Apology: a speech-act set. In N. Wolfson, \& E. Judd (Eds.), Sociolinguistics and language acquisition. Rowley, Mass.: Newbury House. 
Peneva, D. (2016). Challenges in teaching remedial apologies to learners of English as a foreign language. In Todorova et al (Eds.). Studies in Linguistics, Culture and FLT, Vol.1, 117-124.

Richards, J., \& Schmidt, R. W. (2002). Longman dictionary of language teaching and applied linguistics. London: Longman.

Rose, K. R. (1999). Teachers and students learning about requests in Hong Kong. In E. Hinke (Ed.). Culture in second language teaching and learning. Cambridge: Cambridge University Press.

Rose, K. (2000). An exploratory cross-sectional study of interlanguage pragmatic development. Studies in Second Language Acquisition, 22(1), 27-67.

Rose, K. R. (2005). On the effects of instruction in Second Language Pragmatics. System, $33,385-399$.

Schauer, G. (2006). Pragmatic awareness in ESL and EFL contexts: contrast and development. Language Learning, 56 (2), 269-317.

Schmidt, R. (1993). Consciousness, learning and interlanguage pragmatics. In G. Kasper, \& S. Blum-Kulka (Eds.), Interlanguage Pragmatics, (pp. 21-42). New York: Oxford University Press.

Searle, J. R. (1976). A classification of illocutionary acts. Language in Society, 5(01), 1-23.

Thomas, J. (1983). Cross-cultural pragmatic failure. Applied Linguistics, 4, 91-112.

Tilbury, A., Clementson, T., Hendra, L. A., \& Rea, D. (2013). English Unlimited. A2 elementary coursebook. Cambridge: Cambridge University Press.

Trosborg, A. (1987). Apology strategies in natives/non-natives. Journal of Pragmatics, 1, $147-167$. 


\section{Appendix 1}

\section{Questionnaire for teachers}

1. What is pragmatic competence?

2. Can you name some speech acts/ language functions which students need to acquire in English?

3. To what extent to you agree with the following statements:

(1. Strongly Disagree 2. Disagree 3. Neither Agree nor Disagree 4. Agree 5. Strongly Agree)

\begin{tabular}{|c|c|c|c|c|c|}
\hline \multirow{2}{*}{$\begin{array}{l}\text { 1. I am familiar with the concept of } \\
\text { pragmatics. }\end{array}$} & 1 & 2 & 3 & 4 & 5 \\
\hline & & & & & \\
\hline $\begin{array}{l}\text { 2. Pragmatic competence is important for } \\
\text { language learners. }\end{array}$ & & & & & \\
\hline $\begin{array}{l}\text { 3. I evaluate my own pragmatic competence } \\
\text { as very good. }\end{array}$ & & & & & \\
\hline $\begin{array}{l}\text { 4. The instruction of pragmatic competence } \\
\text { should be part of an effective language } \\
\text { teaching program. }\end{array}$ & & & & & \\
\hline $\begin{array}{l}\text { 5. Learners' pragmatic competence should } \\
\text { be part of an effective language testing } \\
\text { program. }\end{array}$ & & & & & \\
\hline $\begin{array}{l}\text { 6. I make my students aware of the } \\
\text { significance of pragmatic competence in } \\
\text { language learning. }\end{array}$ & & & & & \\
\hline $\begin{array}{l}\text { 7. I draw my student's attention to } \\
\text { pragmatic appropriateness. }\end{array}$ & & & & & \\
\hline $\begin{array}{l}\text { 8. I correct learners' pragmatic errors } \\
\text { systematically. }\end{array}$ & & & & & \\
\hline $\begin{array}{l}\text { 9. Politeness is an important aspect of } \\
\text { pragmatics. }\end{array}$ & & & & & \\
\hline 10. Politeness is culture-specific. & & & & & \\
\hline $\begin{array}{l}\text { 11. It is important for students to be aware } \\
\text { of politeness norms when speaking English. }\end{array}$ & & & & & \\
\hline $\begin{array}{l}\text { 12. Students sensitive to impolite or } \\
\text { aggressive verbal behaviour. }\end{array}$ & & & & & \\
\hline
\end{tabular}


4. Can you give examples of:

- polite request

- polite refusal

- polite apology

5. Can you give examples of inappropriate conversation topics when speaking to British/ American people?

6. Can you give examples of inappropriate verbal and nonverbal behaviour when speaking to British/ American people? 